\title{
PERKAWINAN BEDA AGAMA YANG DILAKUKAN DI LUAR NEGERI BERDASARKAN HUKUM POSITIF DI INDONESIA
}

\author{
Soebandi \\ Benny Haryono \\ Program Studi, Fakultas Hukum, Universitas Mahendradatta \\ Jl. Ken arok No 12, Peguyungan Denpasar Utara, Bali 80115 \\ (bennyharyono@gmail.com)
}

\begin{abstract}
ABSTRAK.Setiap agama memiliki ketentuan-ketentuan yang mengatur mengenai perkawinan, sehingga setiap individu wajib patuh dan tunduk pada agamanya masingmasing. Setiap Warga Negara Indonesia yang hendak melakukan perkawinan sudah seharusnya melewati lembaga agamanya masing-masing. Karena perkawinan yang didasari ikatan lahir bathin dapat dikatakan sah, apabila telah memenuhi unsur dalam Pasal 2 ayat (1) Undang-Undang Nomor 1 Tahun 1974, bahwa perkawinan adalah sah apabila dilakukan menurut hukum masing-masing agamanya dan kepercayaannya itu. Maka dari itu, perkawinan wajib dilakukan menurut hukum dari masing-masing agamanya dan kepercayaan itu, kalau tidak perkawinan itu tidak sah. Sementara seluruh agama yang diakui Indonesia tidak memperbolehkan adanya perkawinan yang dilakukan jika kedua calon beda agama. Misalnya bagi agama Kristen perkawinan beda agama ialah tidak sah, karena dilakukan menurut aturan agama Kristen tidak sesuai dengan syaratsyarat yang telah ditentukan dalam perkawinan. Setiap agama yang diakui di Indonesia melarang keras setiap orang untuk melaksanakan perkawinan beda agama karena tidak sesuai dengan hukum agama dan hukum nasional Indonesia. Rumusan Masalah dalam jurnal ini adalah : 1) Bagaimana perkawinan beda agama di luar negeri menurut hukum positif di Indonesia? 2) Bagaimana akibat hukum dari perkawinan beda agama yang dilakukan di luar negeri berdasarkan hukum positif di Indonesia? Jenis Penelitian Penelitian ini akan disusun dengan menggunakan tipe penelitian yuridis normative, yaitu penelitian yang difokuskan untuk mengkaji penerapan kaidah-kaidah atau norma-norma dalam hukum positif. Yuridis Normatif, yaitu pendekatan yang menggunakan konsepsi legis positivis. Konsep ini memandang hukum identic dengan norma-norma tertulis yang dibuat dan diundangkan oleh lembaga atau pejabat yang berwenang. Konsep ini memandang hukum sebagai suatu system normative yang bersifat mandiri, tertutup, dan terlepas dari kehidupan masyarakat yang nyata. Penelitian ini menggunakan pendekatan perundang-undangan (statute approach) dan pendekatan konsep (conceptual approach). Pendekatan perundang-undangan (statute approach) menggunakan aturan hukum yang menjadi focus sekaligus tema sentral dalam penelitian ini. Pendekatan konsep (conceptual approach) ialah penggabungan kata-kata secara tepat dan menggunakan
\end{abstract}


proses pikiran. Terdapat beberapa pasal yang dapat dijadikan dasar dilarangnya perkawinan beda agama yang terdapat dalam Undang-Undang Nomor 1 Tahun 1974 tentang Perkawinan pada pasal 2 ayat (1) dan pasal 8 huruf (f). dalam pasal 2 ayat (1) dikatakan bahwa "Perkawinan adalah sah, apabila dilakukan menurut hukum masingmasing agamanya dan kepercayaannya itu". ${ }^{46}$ Oleh karena itu, sesuai dengan pasal 2 ayat (1) tersebut maka tidak ada perkawinan di luar hukum masing-masing agamanya dan kepercyaannya itu dan sesuai dengan Undang-Undang Dasar 1945. Yang dimaksud dengan hukum masing-masing agama dan kepercayaannya itu termasuk ketentuan perundang-undangan yang berlaku bagi golongan agama dan kepercyaannya sepanjang tidak bertentangan atau tidak ditentukan lain dalam Undang-Undang ini Tindakan pasangan calon suami isteri Warga Negara Indonesia yang berbeda agama kemudian melakukan perkawinan di luar negeri disebut dengan istilah penyelundupan hukum yaitu cara yang dilakukan pasangan calon suami isteri yang memiliki perbedaan keagamaan, tetapi dengan cara melanggar aturan hukum nasionalnya dalam hal ini aturan Pasal 2 ayat (1) Undang-Undang Nomor 1 Tahun 1974 tentang Perkawinan mengenai keabsahan perkawinan akibat penyelundupan hukum perkawinan tersebut berakibat perkawinan tersebut batal demi hukum atau yang dikenal dengan asas "fraus omnia corrumpit". Akibat hukum dari perkawinan beda agama di luar negeri menurut hukum positif di Indonesia antara lain sebagai berikut : 1. Kesulitan dalam Perbuatan Hukum bagi Pasangan yang melakukan perkawinan beda agama di luar negeri. 2. Keabsahan anak yang dilahirkan dari perkawinan beda agama. 3. Hak Mewaris tentang kewarisan khususnya mengenai hak waris anak yang lahir dalam perkawinan beda agama. Perkawinan beda agama juga mengakibatkan kesenjangan social bagi pihak keluarga, masyrakat, dan terutama bagi anak yang dilahirkan dalam perkawinan tersebut.

\section{Kata Kunci : Larangan Perkawinan, Akibat Hukum}

ABSTRACT. Every religion has provisions governing marriage, so everyone must obey and be asked for their respective religions. Every Indonesian citizen who marries must go through their respective religious institutions. Because marriages based on birth bonds can be accepted as valid, it has been agreed to fulfill in Article 2 paragraph (1) of Law Number 1 of 1974, how legal marriages are conducted according to the law of each religion and its beliefs. Therefore, marriages must be carried out according to the law of each religion and belief, otherwise the marriage is not valid. While all religions in Indonesia do not allow marriages to be held if the two candidates are of different religions. For example, for Christians interfaith marriages are not legal, because they are carried out according to the rules of the Christian religion not in accordance with the conditions set out in the marriage. Every religion approved in Indonesia. Expelling everyone to do a marriage different from religion is not in accordance with Indonesian religious and national law. Problem formulations in this journal are: 1) How do interfaith marriages abroad according to positive law in Indonesia? 2) How is the law of interfaith marriages conducted abroad based on positive law in Indonesia? Type of Research This

\footnotetext{
${ }^{46}$ Pasal 2 ayat (1) Undang-Undang Nomor 1 Tahun 1974 tentang Perkawinan
} 
research will be prepared using the type of normative juridical research, namely research that supports to examine the application of the rules or norms in positive law.

Normative juridical, that is the approach that uses the positivist legis conception. This concept views identical law with written norms created and promulgated by authorized institutions or officials. This concept views the law as a normative system that is independent, closed, and independent of real community life. This study uses a statutory approach and a conceptual approach. The statute approach uses the rule of law which is the focus as well as the central theme in this study. The conceptual approach (conceptual approach) is the incorporation of words appropriately and using thought processes. There are several articles that can be used as the basis for the prohibition of interfaith marriages contained in Law Number 1 of 1974 concerning Marriage in article 2 paragraph (1) and article 8 letter (f). in article 2 paragraph (1) it says that "Marriage is legal, if it is done according to the law of each religion and that belief". Therefore, in accordance with article 2 paragraph (1), there are no marriages outside the law of each religion and their beliefs and in accordance with the 1945 Constitution. What is meant by the law of each religion and belief includes legal provisions the laws that apply to religious groups and their beliefs as long as they do not contradict or are not otherwise specified in this Law. Actions of married couples of Indonesian citizens who are of different religions and then conduct marriages abroad are referred to as legal smuggling, that is the way a prospective husband does wives who have religious differences, but by violating the rules of their national law in this case the provisions of Article 2 paragraph (1) of Law Number 1 of 1974 concerning Marriage regarding the validity of the marriage due to smuggling of the marriage law results in the marriage being null and void by law or known as the marriage the principle of "fraus omnia corrum pit ". The legal consequences of interfaith marriages abroad according to positive law in Indonesia include the following: 1. Difficulties in Legal Deeds for Couples who do interfaith marriages abroad. 2. The validity of children born from interfaith marriages. 3. Inheritance rights regarding inheritance, especially regarding inheritance rights of children born in interfaith marriages. Interfaith marriages also result in social inequalities for families, communities, and especially for children born in such marriages.

\section{Keywords: Prohibition of Marriage, Legal Consequences}




\section{A. Latar Belakang}

Di Indonesia, sejak tanggal 2 Januari 1974 perkawinan telah diatur dalam Undang-Undang Nomor 1 Tahun 1974 tentang Perkawinan dan diberlakukan bersamaan dengan peraturan pelaksanannannya ialah Peraturan Pemerintah Nomor 9 Tahun 1975 yang berlaku tanggal 01 Oktober 1975. Peraturan ini berlaku bagi seluruh Warga Negara Indonesia.

Undang-Undang Nomor 1 Tahun 1974 tentang Perkawinan telah memberikan definisi dalam Pasal 1 yang berbunyi " Perkawinan ialah ikatan lahir bathin antara seorang pria dengan seorang wanita sebagai suami istri dengan tujuan membentuk keluarga (rumah tangga) yang bahagia dan kekal berdasarkan Ketuhanan Yang Maha Esa" ${ }^{47}$ Meskipun perkawinan memiliki aturan sendiri dalam UndangUndang Nomor 1 Tahun 1974, bukan berarti Undang-Undang tersebut telah mengatur secara keseluruhan mengenai perkawinan. Dikarenakan, perkawinan bukan hanya mengenai urusan pribadi antara calon suami istri tetapi juga urusan agama, hukum, dan social. Negara Indonesia sendiri memiliki berbagai macam bahasa, budaya, suku, bangsa, dan agama. Dengan perbedaanperbedaan yang ada di Indonesia sendiri akan menimbulkan permasalahan tersendiri bagi Warga Negara Indonesia, salah satunya pada hubungan umat beragama. Dapat kita ambil contoh ialah persoalan perkawinan yang dilakukan antar umat Bergama atau yang biasa disebut dengan perkawinan beda agama.

Setiap agama memiliki ketentuan-ketentuan yang mengatur

\footnotetext{
${ }^{47}$ Pasal 1 Undang-Undang Nomor 1 tahun 1974 Tentang Perkawinan
}

mengenai perkawinan, sehingga setiap individu wajib patuh dan tunduk pada agamanya masing-masing. Setiap Warga Negara Indonesia yang hendak melakukan perkawinan sudah seharusnya melewati lembaga agamanya masing-masing. Karena perkawinan yang didasari ikatan lahir bathin dapat dikatakan sah, apabila telah memenuhi unsur dalam Pasal 2 ayat (1) Undang-Undang Nomor 1 Tahun 1974, bahwa perkawinan adalah sah apabila dilakukan menurut hukum masing-masing agamanya dan kepercayaannya itu. Maka dari itu, perkawinan wajib dilakukan menurut hukum dari masing-masing agamanya dan kepercayaan itu, kalau tidak perkawinan itu tidak sah. ${ }^{48}$

Perkawinan yang sah harus dicatat menurut Peraturan PerundangUndangan yang berlaku hal ini diatur di dalam pasal 2 ayat (2) Undang-Undang No 1 tahun 1974 tentang Perkawinan bahwa " tiap-tiap perkawinan dicatat menurut peraturan perundangundangan berlaku". Dari ketentuan pasal ini dapat disimpulkan bahwa perbuatan pencatatan itu tidaklah menentukan sahnya suatu perkawinan, tetapi menyatakan bahwa peristiwa itu memang ada dan terjadi, jadi sematamata bersifat administrative. ${ }^{49}$

Pada saat ini fakta di masyarakat terdapat pasangan yang berbeda agama melangsungkan perkawinan dan masih berpegang teguh pada agamanya masing-masing, maka akan menimbulkan permasalahan dalam pencatatannya, dikarenakan belum ada peraturan mengenai perkawinan beda agama yang akan menimbulkan ketidakjelasan prosedur

\footnotetext{
${ }^{48}$ Wantjik K Shaleh, 1976, Hukum Perkawinan Di Indonesia, Jakarta : Ghalia Indonesia, hlm 16 ${ }^{49}$ Ibid, hal 17.
} 
dalam melangsungkan perkawinan beda agama tersebut.

Salah satu persoalan perkawinann beda agama adalah tidak dapat diterima baik dari Kantor Urusan Agama maupun Kantor Catatan Sipil. Kondisi tersebut telah dialami oleh beberapa suami isteri yang memiliki perbedaan agama. Selain itu, telah dikemukakan oleh Neng Djubaidah, bagi orang Islam di Indonesia dilarang melakukan perkawinan beda agama karena kemudaratannya lebih besar dibandingkan kemaslatan yang dapat diraih. Dan proses pemurtadan sering terjadi dalam perkawinan beda gama dengan dalih Hak Asasi Manusia. ${ }^{50}$

Sementara seluruh agama yang diakui Indonesia tidak memperbolehkan adanya perkawinan yang dilakukan jika kedua calon beda agama. Misalnya bagi agama Kristen perkawinan beda agama ialah tidak sah, karena dilakukan menurut aturan agama Kristen tidak sesuai dengan syarat-syarat yang telah ditentukan dalam perkawinan. Setiap agama yang diakui di Indonesia melarang keras setiap orang untuk melaksanakan perkawinan beda agama karena tidak sesuai dengan hukum agama dan hukum nasional Indonesia. ${ }^{51}$

Berdasarkan latar belakang yang telah diuraikan diatas, maka penulis tertarik untuk mengadakan penelitian tentang "PERKAWINAN BEDA AGAMA YANG DILAKUKAN DI LUAR NEGERI BERDASARKAN HUKUM POSITIF DI INDONESIA".

\section{B. Rumusan Masalah}

1. Bagaimana perkawinan beda agama di luar negeri menurut hukum positif di Indonesia?

2. Bagaimana akibat hukum dari perkawinan beda agama yang dilakukan di luar negeri berdasarkan hukum positif di Indonesia?

\section{Tujuan Penelitian}

1. Untuk mengetahui dan memahami perkawinan beda agama di luar negeri menjadi sah menurut hukum positif di Indonesia

2. Untuk mengetahui dan memahami akibat hukum dari perkawinan beda agama yang dilakukan di luar negeri berdasarkan hukum positif di Indonesia.

\section{Tinjauan Pustaka}

\section{Pengertian Perkawinan}

Kitab Undang-Undang Hukum Perdata (KUHPer) tidak memuat suatu ketentuan arti atau definisi tentang perkawinan, namun pemahaman perkawinan dapat dilihat dalam Pasal 26 Kitab Undang-Undang Hukum perdata, dalampasal tersebut dikatakan bahwa

Undang-Undang memandang perkawinan hanya dari sudut perhubungannya dengan hukum perdata saja, lain dari itu adalah tidak. Dengan kata lain, bahwa

\footnotetext{
${ }^{5050}$ Neng Djubaidah, 2010, Pencatatan Perkawinan dan Perkawinan Tidak Dicatat Menurut Hukum Tertulis Di Indonesia, Jakarta : Sinar Grafika, hlm 178.
}

\footnotetext{
${ }^{51}$ Rusli dan R. Tama, 1986, Perkawinan Antar Agama dan Masalahnya, Bandung : Pionir Jaya, hlm 11.
} 


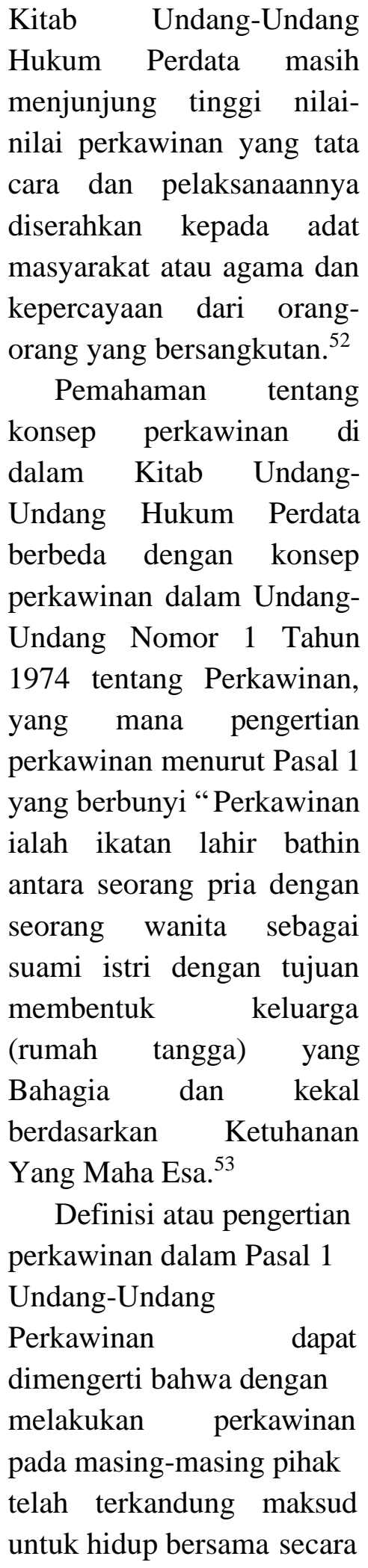

${ }^{52}$ Asyari Abdul Ghofar, 1992, Hukum Perkawinan Antar Agama Menurut Agama Islam, Kristen Dan Undang- Undang Perkawinan, Jakarta : CV. Gramada, hlm 16.

${ }^{53}$ Pasal 1 Undang-Undang Nomor 1 Tahun 1974. abadi, dengan memenuhi hak-hak dan kewajibankewajiban yang telah ditetapkan oleh negara, untuk mencapai keluarga bahagia. $^{54}$

Ikatan perkawinan hanya boleh terjadi antara seorang pria dengan seorang wanita sehingga tidak dimungkinkan terjadi hubungan perkawinan antara pasangan yang sama jenis kelaminnya. Persekutuan atau ikatan antara seorang pria dengan seorang wanita bias dipandang sebagai suamiistri manakala ikatan mereka tersebut didasarkan pada perkawinan yang sah. Sebuah perkawinan dapat dikatakan sah apabila dipenuhinya syarat-syarat tertentu sesuai dengan apa yang telah ditentukan oleh Undang-Undang. Hal ini sesuai dengan pengertian perkawinan menurut $\mathrm{R}$. Wirjono Projodikoro, dimana perkawinan adalah hidup Bersama dari seorang laki-laki dan seorang perempuan yang memenuhi syarat-syarat tertentu. ${ }^{55}$

\section{Syarat-Syarat Perkawinan}

Bagi pasangan yang

\footnotetext{
${ }^{54}$ Rusli dan R.Tama, 2000, Perkawinan Antar Agama Dan Permasalahannya, Pionir Jaya, Bandung, hlm 11.

${ }^{55}$ Wirjono Projodikoro, 1984, Hukum Perkawinan Di Indonesia, Bandung : Sumur Bandung, hlm 7.
} 
hendak melangsungkan perkawinan, harus memenuhi syarat-syarat tertentu untuk sahnya suatu perkawinan. Ikatan antara seorang pria dan seorang wanita dapat dipandang sebagai suami istri, ikatan tersebut didasarkan pada adanya perkawinan yang sah, untuk sahnya

perkawinan harus memenuhi syarat-syarat tertentu yang telah ditentukan oleh UndangUndang Nomor 1 Tahun 1974 tentang Perkawinan.

Supaya perkawinan dapat dilangsungkan, maka calon mempelai harus memenuhi syarat-syarat untuk melangsungkan perkawinan. Syarat-syarat perkawinan di Indonesia diatur dalam Pasal 6, Pasal 7, dan Pasal 11 UndangUndang Nomor 16 Tahun 2019 Perubahan Atas Undang-Undang Nomor 1 Tahun 1974 tentang Perkawinan dan Peraturan Pemerintah Republik Indonesia Nomor 9 Tahun 1975.

Menurut Ko Tjay Sing, syarat-syarat perkawinan yang diatur dalam UndangUndang Perkawinan dan Peraturan Pelaksananya $\begin{array}{lr}\text { Peraturan } & \text { Pemerintah } \\ \text { Nomor 9 Tahun } 1975 \text { dapat } \\ \text { dikelompokkan } & \text { sebagai } \\ \text { berikut }{ }^{56} & \end{array}$

a. Syarat-Syarat Materil

1. Perkawinan harus didasarkan atas persetujuan kedua calon suami istri (Pasal 6 ayat (1) Undang-Undang Nomor 1 Tahun 1974 tentang Perkawinan)

2. Seorang yang belum mencapai umur 21 tahun harus mendapatkan ijin dari kedua orang tuanya (Pasal 6 ayat (2) UndangUndang Nomor 1 Tahun 1974 tentang Perkawinan)

3. Perkawinan diijinkan jika pihak pria sudah mencapai umur 19 tahun dan pihak wanita sudah mencapai umur 19 tahun (Pasal 7 ayat (1) Undang-Undang Nomor 16 Tahun 2019 sebagai Perubahan Atas

${ }^{56}$ Ko Tjay Sing, 1981, Hukum Perdata Jilid I Hukum Keluarga, Semarang : Itikad Baik, hlm 134131. 
Undang-Undang

Nomor 1 Tahun

1974 tentang

Perkawinan)

b. Syarat-Syarat Formal

Syarat-syarat formal

terdiri dari

formalitas-

formalitas yang

mendahului

perkawinan. ${ }^{57}$

Syarat-syarat formal terdiri dari 3 (tiga)

tahap, yaitu :

1. Pemberitahuan

Kepada Pegawai

Pencatat

Perkawinan Di

Kantor Catatan

Sipil bagi yang non-muslim.

2. Penelitian Syarat-

Syarat

perkawinan.

Penelitian syarat-

syarat

perkawinan

dilakukan

setelah ada

pemberitahuan

akan perkawinan

oleh Pegawai

Pencatat

Perkawinan.

Penelitian

syarat-syarat

perkawinan

memeriksa

apakah syarat-

syarat perkawinan

sudah terpenuhi

atau belum dan

apakah ada

halangan

perkawinan

menurut

Undang-

Undang.

3. Pengumuman

Tentang

Pemberitahuan

Untuk

Melangsungkan

Perkawinan.

Tujuan diadakan

pengumuman

ini, yaitu untuk

memberi

kesempatan

kepada umum

untuk

mengetahui dan

mengajukan

keberatan-

keberatan

terhadap

dilangsungkann

ya perkawinan.

Pengumuman

perkawinan

ditandatangani

oleh Pegawai

Pencatat

Perkawinan dan

memuat hal

ihwal orang

yang akan

melangsungkan

perkawinan itu

${ }^{57}$ Ko Tjay Sing, Op. Cit, hlm 114. 


\begin{abstract}
akan
dilangsungkan. ${ }^{58}$

Dengan mengingat

banyak hal-hal yang mungkin

timbul dikemudian hari

setelah adanya suatu

perkawinan, baik dari

pasangan suami istri itu

sendiri maupun dari keluarga

termasuk dari orang tua

diharapkan tidak adanya

perpecahan dalam

perkawinan tersebut

dikarenakan tidak adanya

kecocokan atau tidak adanya

penyesuaian sebelumnya

yang disebabkan oleh

pelaksanaan perkawinan

tersebut bukan kemauan dari

salah satu pihak saja, baik

hanya kemauan dari

pasangan itu sendiri atau

kemauan dari keluarga

ataupun orang tua. Dengan

adanya persetujuan

perkawinan maka resiko dan tanggungjawab dari

perkawinan tersebut dipikul secara bersama-sama.
\end{abstract}

\section{Tujuan Perkawinan}

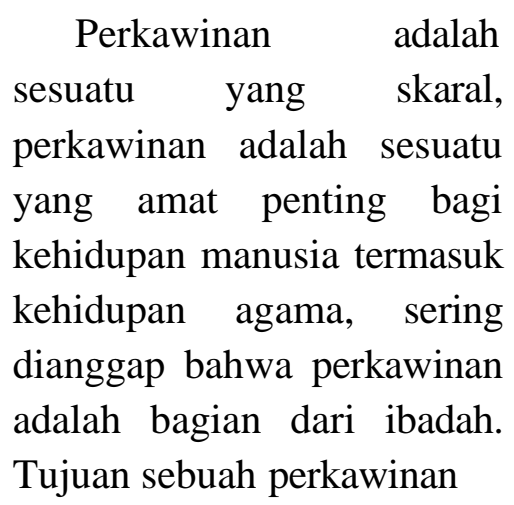

bagi orang beragama harus merupakan suatu alat untuk menghindarkan diri dari perbuatan buruk dan menjauhkan diri dari dosa.

Tujuan perkawinan diatur dalam Pasal 1 UndangUndang Nomor 1 Tahun 1974 tentang Perkawinan ialah membentuk keluarga (rumah tangga) yang bahagia dan kekal berdasarkan Ketuhanan Yang Maha Esa. Dengan berdasarkan Ketuhanan Yang Maha Esa maka perkawinan mempunyai hubungan yang sangat erat dengan agama atau kerohanian, dalam hal perkawinan disetiap agama pasti mempunyai tujuan yang jelas, tujuan perkawinan diharapkan dapat membuat suatu ketenangan dalam hubungan rumah tangga dengan dasar agama.

\section{Asas-Asas Perkawinan}

Dalam suatu perkawinan perlu adanya suatu ketentuan yang menjadi dasar atau prinsip dari pelaksanaan perkawinan. Mengenai prinsip atau dasar perkawinan tersebut telah ada pengaturannya di dalam Undang- Undang Nomor 1 Tahun 1974 tentang Perkawinan.

\footnotetext{
${ }^{58}$ K. Wantjik Saleh, Op. Cit, hlm 19.
} 
Seperti

yang

dikemukakan oleh Djaren

saragih bahwa dalam

Undang-Undang Nomor 1

Tahun 1974 tentang

Perkawinan ditentukan

prinsip-prinsip perkawinan

yang telah disesuaikan

dengan perkembangan dan

tuntutan zaman yang

pengaturannya terdapat

dalam penjelasan umum

dari Undang-Undang

Nomor 1 Tahun 1974

tentang Perkawinan. ${ }^{59}$

Terdapat 6 (enam) asasasas perkawinan yang termuat dalam Penjelasan

Umum Undang-Undang

Nomor 1 Tahun 1974

tentang Perkawinan, yaitu sebagai berikut ${ }^{60}$ :

1. Tujuan Perkawinan adalah membentuk keluarga yang bahagia dan kekal.

2. Dalam UndangUndang Nomor 1

Tahun 1974 tentang

Perkawinan

dinyatakan bahwa

perkawinan adalah

sah apabila

perkawinan tersebut

dilakukan menurut

hokum masing-

masing dan

kepercayaannya

tersebut dan perkawinan harus

dicatatkan kepada

Pegawai Pencatat

Perkawinan di Kantor

Catatan Sipil bagi

non-muslim.

3. Undang-Undang

Nomor 1 Tahun 1974

tentang Perkawinan

mengatur

asas

monogami.

4. Undang-Undang

Nomor 1 Tahun 1974

tentang Perkawinan

menganut prinsip,

bahwa calon suami

istri tersebut harus

telah masak jiwa

raganya untuk dapat

melangsungkan

perkawinan, hal ini

dimaksudkan agar

dapat mewujudkan

tujuan perkawinan

secara baik tanpa

berakhir pada

perceraian dan

mendapat keturunan

yang baik dan sehat.

5. Karena tujuan

perkawinan adalah

untuk membentuk

keluarga yang

bahagia dan kekal,

maka Undang-

Undang Nomor 1

Tahun 1974 tentang

Perkawinan

menganut prinsip

${ }^{59}$ Djaren Saragih, 1980, Himpunan Peraturan-

Peraturan Dan Perundang-Undangan Di Bidang

Perkawinan Indonesia, Bandung : Tarsito, hlm 137 138.

${ }^{60} \mathrm{Ibid}$ 
untuk mempersulit terjadinya perceraian. Untuk melakukan perceraian harus dengan dasar atau alas an-alasan tertentu serta harus dilakukan dan diputuskan oleh Pengadilan.

6. Hak dan kedudukan istri adalah seimbang dengan hak dan kedudukan suami, baik dalam kehidupan rumah tangga maupun dalam pergaulan di masyarakat, sehingga dengan demikian makan segala sesuatu dalam keluarga dapat dirundingkan dan diputuskan bersama oleh suami istri. ${ }^{61}$

\section{Perkawinan Beda Agama}

Perkawinan antar pemeluk agama yang berbeda adalah suatu perkawinan yang dilakukan oleh seorang pria dan seorang wanita yang memeluk agama dan kepercayaan yang berbeda antara satu dengan yang lainnya. ${ }^{62}$ Perkawinan beda agama juga bisa terjadi

${ }^{61} \mathrm{Ibid}$

${ }^{62}$ Abdurrahman dan Ribuan Syahrani, 1978, Masalah-Masalah Hukum Perkawinan Di Indonesia, Bandung : Alumni, hlm 11. antara beda kewarganegaraan yaitu pria ataupun wanita salah satunya warga negara asing dan juga memiliki perbedaan agama atau kepercayaan.

\section{E. Metode Penelitian}

\section{Jenis Penelitian}

$\begin{array}{lr}\text { Penelitian } & \text { ini } \\ \text { disusun } & \text { dengan } \\ \text { menggunakan } & \text { tipe } \\ \text { penelitian } & \text { yuridis }\end{array}$
normative, yaitu penelitian yang difokuskan untuk mengkaji penerapan kaidahkaidah atau norma-norma dalam hukum positif. $^{63}$ Yuridis Normatif, yaitu pendekatan yang menggunakan konsepsi legis positivis. Konsep ini memandang hukum identic dengan norma-norma tertulis yang dibuat dan diundangkan oleh lembaga atau pejabat yang berwenang. Konsep ini memandang hukum sebagai suatu system normative yang bersifat mandiri, tertutup, dan terlepas dari kehidupan masyarakat yang nyata. ${ }^{64}$

\section{Pendekatan Penelitian}

\footnotetext{
${ }^{63}$ Johnny Ibrahim, 2006, Teori dan Metodelogi Penelitian Hukum Normatif, Malang : Bayumedia Publishing, , hlm 295.

${ }^{64}$ Ronny Hanitijo Soemitro, 1988, Metodelogi Penelitian Hukum dan Jurimetri, Jakarta : Ghalia Indonesia, hlm $13-14$.
} 
Penelitian ini

menggunakan pendekatan perundang-undangan

(statute approach) dan

pendekatan konsep

(conceptual approach).

Pendekatan perundang-

undangan (statute

approach) menggunakan aturan hukum yang menjadi focus sekaligus tema sentral dalam penelitian ini. Pendekatan konsep (conceptual approach) ialah penggabungan kata-kata secara tepat dan menggunakan proses pikiran. ${ }^{65}$

\section{Jenis Bahan Hukum}

Jenis bahan hukum dalam
penelitian normative ini
terbagi menjadi 2 (dua)
bahan hukum antara lain
sebagai berikut :
a. Bahan Hukum Primer
- Undang-Undang
Dasar 1945
- Undang-Undang
Nomor 1 Tahun 1974
tentang Perkawinan.
- Peraturan Pemerintah
Republik Indonesia
Nomor 9 Tahun 1975
Pelaksanaan Undang-
Undang Nomor 1
Tahun 1974 tentang
Perkawinan.

${ }^{65}$ Johnny Ibrahim, 2006, Teori dan Metodelogi Penelitian Hukum Normatif, Malang : Bayumedia Publishing, , hlm 306.
- Undang-Undang

Nomor 35 Tahun 2014 tentang

Perubahan Atas

Undang-Undang

nomor 23 Tahun 2002

tentang Perlindungan

Anak

- Undang-Undang

Nomor 7 Tahun 1989

tentang Peradilan

Agama

b. Bahan Hukum Sekunder

- Buku-Buku tentang

Perkawinan

- Pendapat para ahli

- Tulisan-Tulisan

Ilmiah yang berkaitan dengan hal yang diteliti.

\section{Teknik Analisis Bahan Hukum}

Teknik analisis bahan hukum yang digunakan ialah analisis normative, merupakan cara menginterpretasikan dan mendiskusikan bahan hasil penelitian berdasarkan pada pengertian hukum, norma hukum, teori-teori hukum serta doktrin yang berkaitan dengan pokok permasalahan. 
F. Pembahasan

1. Perkawinan Beda Agama Di Luar Negeri Menurut Hukum Positif Di Indonesia

Undang-Undang Nomor

1 Tahun 1974 tentang

Perkawinan tidak melarang perkawinan beda agama, tetapi juga tidak mengatur dengan tegas perkawinan beda agama. Namun dalam Pasal 2 ayat (1) UndangUndang Nomor 1 Tahun 1974 ditafsirkan perkawinan antara pasangan yang seagama.

Terdapat beberapa pasal yang dapat dijadikan dasar dilarangnya perkawinan beda agama yang terdapat dalam Undang-Undang Nomor 1 Tahun 1974 tentang Perkawinan pada pasal 2 ayat (1) dan pasal 8 huruf (f). dalam pasal 2 ayat

(1) dikatakan bahwa "Perkawinan adalah sah, apabila dilakukan menurut hukum masing-masing agamanya dan kepercayaannya itu". ${ }^{66}$ Oleh karena itu, sesuai dengan pasal 2 ayat (1) tersebut maka tidak ada perkawinan di luar hukum masing- masing agamanya dan kepercyaannya itu dan sesuai dengan UndangUndang Dasar 1945. Yang

${ }^{66}$ Pasal 2 ayat (1) Undang-Undang Nomor 1 Tahun 1974 tentang Perkawinan

${ }^{67}$ Undang-Undang Dasar 1945. dimaksud dengan hukum masing-masing agama dan kepercayaannya itu termasuk ketentuan perundang-undangan yang berlaku bagi golongan agama dan kepercyaannya sepanjang tidak bertentangan atau tidak ditentukan lain dalam Undang-Undang ini. ${ }^{67}$

Menurut pasal 2 ayat (1) Undang-Undang Nomor 1 Tahun 1974 dapat dipahami bahwa Undang-Undang menyerahkan kepada masing-masing agama untuk menentukan cara-cara dan syarat-syarat pelaksanaan perkawinan, disamping cara-cara dan syarat-syarat yang telah ditetapkan oleh negara.

Dalam

perspektif agama-agama yang diakui di Indonesia, perkawinan beda agama ktidak dibenarkan karena tidak sesuai dengan hukum agama-agama yang diakui di Indonesia. Argumentasi ini diperkuat dengan adanya Pasal 8 huruf (f) bahwa "perkawinan dilarang antara dua orang yang mempunyai hubungan yang oleh agamanya atau peraturan lain yang berlaku, dilarang kawin". ${ }^{68}$
${ }^{68}$ Pasal 8 huruf (f) Undang-Undang Nomor 1 Tahun 1974 tentang Perkawinan. 
Tindakan pasangan

calon suami isteri Warga Negara Indonesia yang berbeda agama kemudian melakukan perkawinan di luar negeri disebut dengan istilah penyelundupan hukum yang dalam bahasa Belanda dikenal dengan "wetsontduiking", dan istilah Inggris dengan "fraudulent creation of point contact" ${ }^{\prime 9}$ yaitu cara yang dilakukan pasangan calon suami isteri yang memiliki perbedaan keagamaan, tetapi dengan cara melanggar aturan hukum nasionalnya dalam hal ini aturan Pasal 2 ayat (1) Undang-Undang Nomor 1 Tahun 1974 tentang Perkawinan mengenai keabsahan perkawinan akibat penyelundupan hukum perkawinan tersebut berakibat perkawinan tersebut batal demi hukum atau yang dikenal dengan asas "fraus omnia corrumpit".

2. Akibat Hukum Dari Perkawinan Beda Agama Yang Dilakukan Di Luar Negeri Berdasarkan Hukum Positif Di Indonesia

1. Kesulitan dalam Perbuatan Hukum

${ }^{69}$ Sudargo Gautama, 1987, Pengantar Hukum Perdata Internasional Indonesia, Bandung : Bina Cipta, hlm 148.
Pasangan suami isteri juga akan mengalami kesulitan yang berkaitan dengan urusan perbuatan hukum yang terkait dengan perkawinan. Akta perkawinan merupakan bukti otentik dari Kantor Catatan Sipil. Pencatatan perkawinan mebantu suami ataupun isteri untuk melakukan perbuatan hukum. Contohnya tidak dapat haknya sebagai seorang istri ataupun suami, dan mengenai status anak perkawinan yang tidak dicatatkan.

2. Keabsahan Anak Menurut Undang-Undang Nomor 1 Tahun 1974 tentang Perkawinan dalam Pasal 42 yang berbunyi " Anak yang sah adalah anak yang dilahirkan dalam atau sebagai akibat perkawinan yang sah. ${ }^{70}$ Dan dalam Pasal 43 ayat (1) berbunyi “ Bahwa anak yang lahir di luar perkawinan hanya mempunyai hubungan perdata dengan ibunya dan keluarga ibunya". ${ }^{71}$

Mengenai kedudukan hukum anak yang lahir dari pasangan perkawinan beda agama ini, kita

\footnotetext{
${ }^{70}$ Pasal 42 Undang-Undang Nomor 1 tahun 1974 tentang Perkawinan

${ }^{71}$ Pasal 43 ayat (1) Undang-Undang Nomor 1 tahun 1974 tentang Perkawinan.
} 
melihat pada ketentuan

Pasal 42 Undang-

Undang Nomor 1 Tahun

1974

tentang

Perkawinan yang

menyebutkan bahwa

anak yang sah adalah

anak yang dilahirkan

dalam atau sebagai

akibat perkawinan yang

sah.

Selain itu, orang tua yang berbeda agama juga perlu memperhatikan ketentuan Pasal 42 Undang-Undang Nomor 35 Tahun 2014 tentang Perubahan Atas Undang-Undang nomor 23 Tahun 2002 tentang Perlindungan Anak yang berbunyi ${ }^{72}$ :

1. Setiap anak mendapat perlindungan untuk beribadah menurut agamanya.

2. Sebelum anak dapat menentukan

pilihannya, agama yang dipeluk anak mengikuti agama orang tuanya. ${ }^{73}$

Di dalam Penjelasan Pasal 42 ayat (2) UndangUndang Nomor 35 Tahun 2014 tentang Perubahan Atas Undang-Undang nomor 23 Tahun 2002

${ }^{72}$ Pasal 42 Undang-Undang Nomor 35 Tahun 2014 tentang Perubahan Atas Undang-Undang nomor 23 Tahun 2002 tentang Perlindungan Anak

${ }^{73}$ Ibid tentang Perlindungan

Anak diterangkan bahwa anak dapat menentukan agama pilihannya apabila anak tersebut telah berakal dan bertanggung jawab, serta memenuhi syarat dan tata cara sesuai dengan ketentuan peraturan perundangundangan yang berlaku.

3. Hak Mewaris

Secara umum perkawinan beda agama sangat berpotensi menimbulkan persoalan-persoalan hukum tersendiri, baik kepada pasangan suami isteri maupun kepada pihak ketiga atau pihak luar termasuk hak waris anak yang lahir dari perkawinan beda agama. $^{74}$ Keabsahan perkawinan yang akan menimbulkan hak dan kewajiban antara suami isteri. Hak isteri terhadap nafkah dan harta bersama sepenuhnya tergantung kepada ada tidaknya perkawinan yang sah sebagai dasar hukumnya. Hal ini dikarenakan anak yang lahir dari perkawinan
${ }^{74}$ Purwanto, 2008, Hak Mewaris Anak Yang Lahir Dari Perkawinan Beda Agama, Thesis Program Study Magister Kenotariatan, Program Pascasarjana Universitas Diponegoro, hlm 20. 
yang tidak sah hanya mempunyai hubungan hukum dengan ibunya $^{75}$, sebagaimana diatur dalam Pasal 43 ayat (1) UndangUndang Nomor

1 Tahun 1974 tentang Perkawinan yang berbunyi : "Anak yang dilahirkan di luar perkawinan hanya mempunyai hubungan perdata dengan ibunya dan keluarga ibunya", 76 sehingga segala hak anak terhadap bapaknya akan hilang dan tidak diakui oleh hukum.

Apabila persoalan kewarisan dilihat dari aspek keadilan, maka larangan perkawinan beda agama jelas lebih melindungi hak kewarisan masingmasing. Hal ini disebabkan anak-anak tidak mungkin beragama kembar, karena agama ialah masalah keyakina. Konsekuensinya anakanak hanya akan seagama dengan satu satu dari orang tuanya dan atau bisa menganut agama lain yang dianut oleh kedua orang tuanya. ${ }^{77}$ Apabila anak seagama dengan salah
${ }^{76}$ Pasal 43 ayat (1) Undang-Undang Nomor 1 tahun 1974 tentang Perkawinan. 
satu orang tuanya,

maka ia hanya akan

mendapatkan

h

ak kewarisan dari

bapak ataupun ibunya

saja yang seagama.

Pada akhirnya masalah

kewarisan khususnya

mengenai hak waris

anak yang lahir dalam

perkawinan

beda

agama, dikembalikan

kepada masyarakat

khususnya pihak-

pihak yang

bersengket

a. Apakah akan mengacu atau tunduk pada hukum agamanya atau hukum lainnya Hukum Perdata (KUH Perdata) atau Hukum

Adat, karena hal tersebut

memang

dimungkinkan oleh ketentuan hukum

yang berlaku yaitu

Undang- Undang

Nomor 7 Tahun 1989

tentang Peradilan

Agama,

dalam

Penjelasan

Umum

disebutkan bahwa

para pihak

sebelum

berperkara mempertimbangk untuk memilih hukum apa yang dipergunakan dalam pembagian warisan. Sehingga selama masih terdapat pluralisme hukum

${ }^{77}$ R. Wirjono Prodjodikoro, 1983, Hukum Waris Di Indonesia, Bandung : Penerbit Sumur, hlm 33. 


\begin{abstract}
waris, maka hal tersebut menjadi hambatan hak mewaris anak yang lahir dalam perkawinan beda agama. Ketentuan hukum mana yang berlaku, hal ini karena masing-masing pihak (pewaris maupun ahli waris) tentunya tetap berpegang teguh pada ketentuan hukum dimana dia tunduk khususnya hukum agama yang dianut. ${ }^{78}$
\end{abstract}

\section{G. Penutup}

\section{Kesimpulan}

Dari uraian pembahasan yang penulis bahas diatas maka penulis dapat menarik beberapa kesimpulan antara lain sebagai berikut :

1. Tindakan pasangan calon suami isteri Warga Negara Indonesia yang berbeda agama kemudian melakukan perkawinan di luar negeri disebut dengan istilah penyelundupan hukum yaitu cara yang dilakukan pasangan calon suami isteri yang memiliki perbedaan keagamaan, tetapi dengan cara melanggar aturan hukum nasionalnya dalam hal ini aturan Pasal 2 ayat (1)
Undang-Undang Nomor

1 Tahun 1974 tentang Perkawinan mengenai keabsahan perkawinan akibat penyelundupan hukum perkawinan tersebut berakibat perkawinan tersebut batal demi hukum atau yang dikenal dengan asas "fraus omnia corrumpit".

2. Akibat hukum dari perkawinan beda agama di luar negeri menurut hukum positif di Indonesia antara lain sebagai berikut :

- Kesulitan dalam Perbuatan Hukum bagi Pasangan yang melakukan perkawinan beda agama di luar negeri.

- Keabsahan anak yang dilahirkan dari perkawinan beda agama.

- Hak Mewaris tentang kewarisan khususnya mengenai hak waris anak yang lahir dalam perkawinan beda agama.

Perkawinan beda agama juga mengakibatkan kesenjangan social bagi pihak keluarga, masyrakat, dan terutama

${ }^{78}$ H. Amin Husein Nasution, 2012, Hukum Kewarisan, Jakarta : PT. RajaGrafindo Persada, hlm. 75. 
bagi anak yang

dilahirkan

dalam

perkawinan tersebut.

\section{Saran}

1. Dengan diberiakukannya Undang-Undang Nomor 1 Tahun 1974 tentang Perkawinan, terjadi pembatasan untuk melakukan perkawinan antara mereka yang berbeda agama.

Sayangnya pembatasan ini tidak diawasi secara ketat, sehingga banyak dilakukan penyelundupan hukum agar perkawinan tersebut menjadi dianggap sah. Melihat keadaan sosial masyarakat Indonesia, perkawinan antar pemeluk agama yang berbeda merupakan permasalahan yang tidak dapat dihindari karena terdapatnya pluralisme agama di Indonesia. Unluk itu agar tidak terus terjadi penyelundupan hukum dalam bidang hukum perkawinan khususnya dalam perkawinan antara mereka yang berbeda agama diperiukan pengaturan yang dapat mengakomodasi kebutuhan semua pihak.

2. Hendaknya perkawinan beda agama ini tidak dilakukan oleh pasangan yang akan menikah. Hal ini mengingat dampak yang ditimbulkannya berpengaruh terhadap masa depan keluarga, anak dan harta benda. Selain itu yang paling penting bahwa tidak ada satu agamapun yang membolehkan adanya perkawinan beda agama. Hal ini juga merugikan bagi pihak anak untuk memberi perlindungan kepada anak serta menempatkan hak anak hasil perkawinan tersebut.

\section{DAFTAR PUSTAKA}

Wantjik K Shaleh, 1976, Hukum Perkawinan Di Indonesia, Jakarta : Ghalia Indonesia

R. Wirjono Prodjodikoro, 1983, Hukum Waris Di Indonesia, Bandung : Penerbit Sumur

H. Amin Husein Nasution, 2012, Hukum Kewarisan, Jakarta : PT. RajaGrafindo Persada.

Purwanto, 2008, Hak Mewaris Anak Yang Lahir Dari Perkawinan Beda Agama, Thesis Program Study Magister Kenotariatan, Program Pascasarjana Universitas Diponegoro,

Sudargo Gautama, 1987, Pengantar Hukum Perdata Internasional Indonesia, Bandung : Bina Cipta 
Ronny Hanitijo Soemitro, 1988,

Metodelogi Penelitian Hukum dan

Jurimetri, Jakarta : Ghalia Indonesia.

Johnny Ibrahim, 2006, Teori dan Metodelogi Penelitian Hukum Normatif,

Malang : Bayumedia Publishing.

Abdurrahman dan Ribuan Syahrani, 1978, Masalah-Masalah Hukum Perkawinan Di Indonesia, Bandung : Alumni.

Djaren Saragih, 1980, Himpunan Peraturan-Peraturan Dan PerundangUndangan Di Bidang Perkawinan Indonesia, Bandung : Tarsito.
Wirjono Projodikoro, 1984, Hukum

Perkawinan Di Indonesia, Bandung :

Sumur Bandung.

Ko Tjay Sing, 1981, Hukum Perdata Jilid I Hukum Keluarga, Semarang : Itikad Baik,

Rusli dan R.Tama, 2000, Perkawinan Antar Agama Dan Permasalahannya, Pionir Jaya Bandung. 